\title{
Impact of Biochar Soil Amendment on Tomato mosaic virus Infection, Growth and Nutrients Uptake of Tomato Plants
}

\author{
Maha A. Kawanna ${ }^{1 *}$, Ahmed F. El-Bebany ${ }^{1}$ and Ayman B. A. Basyony ${ }^{1}$
}

\begin{abstract}
Biochar soil amendment was applied as an eco-friendly approach to control Tomato mosaic virus (ToMV) and improve tomato growth and nutritional status. Three concentrations of biochar, $0.5,1.0$ and $1.5 \%$ were used as soil amendments. Using biochar at the rate of 1 and $1.5 \%$ reduced the ToMV incidence and delayed symptoms appearance as compared with plants grown in nonamended soil. Infection percentage and disease severity of ToMV were reduced by 33.3 and $50 \%$, respectively, 15 days after inoculation of plants of soil amended with $1.5 \%$ biochar. ToMV relative concentration, using indirect ELISA was significantly reduced in plants of biochar $1 \%$ and $1.5 \%$ treatments. The lowest virus concentration was recorded at 21 days after inoculation in plants of $1.5 \%$ biochar amended soil. The shoot fresh weight was increased at biochar rates of 1.5 and $0.5 \%$ in non-infected and ToMV infected tomato, respectively. Significant increase was obtained in shoot $K$ content amended with 1.0 and $1.5 \%$ biochar treatments of healthy and ToMVinfected tomato plants, respectively. Whereas, shoot $\mathrm{Na}$ content was diminished in infected plants grown in biochar amended soil at all tested biochar concentrations. Overall, the biochar application to soil enhanced resistance to ToMV infection, stimulated growth and $K$ content increment and $\mathrm{Na}$ content decrement in tomato plants. In conclusion, application of biochar to agricultural soil could be considered a practical tool for minimizing the change effects of climate through carbon sequestration, improve plant productivity and increase diseases tolerance for sustainable agriculture.
\end{abstract}

Keywords: Tomato, Biochar; ToMV; Resistance; Potassium; Sodium.

\section{INTRODUCTION}

Tomato (Solanum lycopersicum L.) is one of the world's most economic crop. A total of 177 million tons of tomatoes were produced worldwide in 2016 (FAO, 2018). Total production of tomato has been affected by the prevalence of tomato viral diseases (Ong et al., 2020). Unfortunately, tomato can be infected by about 136 viral species (Brunt et al., 1996).

Tomato mosaic virus (ToMV) the type species of Tobamoviruses in family Virgaviridae is widespread wherever tomato is grown (ICTV, 2014; Sastry et al.,
2019). It led to serious losses in tomato productivity, damages leaves, flowers and fruits and causes stunting of the plants (Agrios, 2005).

Biochar is a solid-rich by-product of biomass, obtained by pyrolysis or by high temperatures under a low oxygen atmosphere. It is usually added to the soil to improve its fertility and increase crop productivity (Lehmann et al., 2006; Hussain et al., 2017). Biochar was demonstrated as plant diseases suppressor in several pathosystems (Elad et al., 2011). Soil amendment with biochar, prepared from corn stalk, straw rice, straw of faba bean and cotton stalk to soil, declined the severity of number of pathogenic fungi on faba bean plants (Mostafa and Shaban, 2019). Also, the severity of the foliar disease of tomato caused by Botrytis cinerea was proved to be suppressed by $50 \%$ in plants grown in biochar amended soil (Mehari et al., 2015). Few works have been done on the effects of biochar soil amendment on plant virus infection (Khalifa, 2017; Zeshan et al., 2018; Bonanomi et al., 2020). The biochar application to agricultural soils increased the growth measurements of several plants including tomato (Kuppusamy et al., 2016; Agbna et al., 2017). The improvement of plant growth may refer to increasing the beneficial bacteria and fungi in the soil rhizosphere, enhancing soil water holding capacity and up taking nutrients (Graber et al., 2010; Hussain et al., 2017).

The objectives of the current research were to investigate if soil amendment with biochar could protect tomato plants from ToMV infection and to assess the effects of biochar on the growth and the essential nutrients uptake in the shoots of tomato plants.

\section{MATERIALS AND METHODS}

\section{Source of biochar and characterization}

Rice husk biochar (RHB) used in the current study was obtained from Prof. Maher Saleh, Department of Soil \& Water Science, Faculty of Agriculture, Alexandria University, Alexandria, Egypt and was previously characterized (Mahmoud et al., 2011).

DOI: 10.21608/asejaiqjsae.2021.200962

${ }^{1}$ Department of Plant Pathology, Faculty of Agriculture, El-Shatby,

Alexandria University, Alexandria, Egypt.

*Corresponding author: mahakawanna@yahoo.com

Received September 20, 2021, Accepted, October 24, 2021. 
Plant materials, biochar treatments and experimental design

The rice husk biochar was mixed with sandy clay soil at the rates of $0,0.5,1$ and $1.5 \%(\mathrm{w} / \mathrm{w})$. Each pot was filled with $2 \mathrm{~kg}$ of the respective biochar treatment. Twenty-four pots represent eight biochar treatments were used in this experiment. Three replicates were used for each treatment. Seedlings of tomato plants (cv. 023) of 21 days old were transplanted; one seedling in each pot. The plants were grown in a greenhouse at 20 to $26{ }^{\circ} \mathrm{C}$ with a natural day light regime, irrigated and fertilized as needed.

Fourteen days after transplanting, pots were subdivided into two sets (each of 12 pots). Tomato plants of the first set were mechanically inoculated with ToMV and plants of the other set were left uninoculated. The experimental units (pots) were arranged in a randomized complete design. The experiment was performed under greenhouse condition at Plant Pathology Dept., Faculty of Agriculture, Alexandria University, Alexandria, Egypt.

Virus source, preparation of viral inoculum and tomato inoculation

Tomato mosaic virus (ToMV) used in this study were obtained from the Virology Lab. Collection, Department of Plant Pathology, Faculty of Agriculture, Alexandria University, Egypt. ToMV was maintained on Nicotiana tabacum cv. Turkish, which served as virus source plants for subsequent studies. Except otherwise stated, virus inoculum was set by grinding infected leaf tissues $(1: 10 \mathrm{w} / \mathrm{v})$ in $0.01 \mathrm{M}$ sodium phosphate buffer ( $\mathrm{pH}$ 7.0) containing $0.5 \% \quad 2$ mercaptoethanol using mortar and pestle. Leaves of tomato plants were first dusted with carborundum (600 mesh) then mechanically inoculated with a freshly prepared viral inoculum using forefinger. Plants of the control set received the same treatment, but without virus.

\section{Effect of biochar soil amendment on ToMV infection of tomato plants}

To assess the efficacy of soil amendment with different concentrations of biochar on ToMV infection of tomato plants, percentage of ToMV infection and disease severity were recorded fifteen and thirty days after virus inoculation. Relative virus concentration was estimated at 15, 21, 28 and 35 days after inoculation using indirect enzyme linked immunosorbent assay (indirect ELISA).

\section{Disease severity}

Disease index was rated using the following scale: 0 $=$ no symptoms, $1=$ vein clearing, $2=$ moderate mosaic and mottle, $3=$ severe mosaic, blistering and leaf curling, 4= severe mosaic, leaf malformation, reduction in size and plant stunting.

Disease index (DI) was calculated from the disease rating using the following formula as reported by Raupach et al., (1996).

$$
\left.\left[\sum \text { (rating No. } \times \text { No. plants in rating }\right) \times 100\right]
$$

$\mathrm{DI}=$

$$
\text { (total No. plants } \times \text { highest rating) }
$$

\section{Indirect ELISA}

Leaf samples including top, middle and bottom leaves of tomato plants were collected for serological assay after 15, 21, 28 and 35 days of ToMV inoculation. ToMV relative concentration was determined by indirect ELISA first reported by Koenig (1981) and modified by Fegla et al., (1997). The polyclonal antiserum against ToMV used in this research was locally produced in Plant Virology Lab., Plant Pathology Department, Faculty of Agriculture, Alexandria University, Egypt. ELISA values, measured using Universal automated microplate reader ELx 800, were expressed as absorbance at $405 \mathrm{~nm}$. Samples displaying absorbance value exceeded twice that of the absorbance value of the healthy control were considered positive (Hančević et al., 2012; Kawanna and Fegla, 2015).

\section{Growth parameters and nutrient analyses}

After 35 days of ToMV inoculation, tomato plants were harvested. Fresh and dry weights of shoot systems were recorded. Concentrations of $\mathrm{N}, \mathrm{P}, \mathrm{K}, \mathrm{Ca}, \mathrm{Mg}, \mathrm{Na}$ and $\mathrm{S}$ elements were determined. Nitrogen was measured using Microkjeldahal procedure. $\mathrm{P}$ and $\mathrm{K}$ elements were determined using Ammonium Stannous Chloride method for P (A.O.A.C., 1992) and Flame Photometer for K (Chapman and Pratt, 1961). Calcium and Magnesium were determined by the versenate method using eiro chrome black $\mathrm{T}$ and ammonium purpurate indicators for $\mathrm{Ca}$ and $\mathrm{Mg}$, respectively (Cheng and Bray, 1951). Potassium cyanide was added to prevent the aluminum and iron interference (Johnson and Ulrich, 1959). Sodium was determined in leaf tissues as described by Brown and Lilliland, (1946). Sulfur content was determined as reported by Butters and Chenery, (1959).

\section{Statistical analysis}

Data obtained were statistically analysed using analysis of variance (ANOVA) according to SAS software program (SAS, 1997). Comparison among means was made via the least significant differences test (LSD) at $\leq 5 \%$ level of probability. 


\section{RESULTS AND DISCUSSION}

\section{Effect of biochar soil amendment on ToMV infection of tomato plants}

Application of biochar led to significant increases of plant growth and production of several crops (Silva et al., 2017). Data in Table (1) indicated that soil amendment with biochar decreased the viral disease prevalence. This prevalence was noticeable at 15 days after inoculation then increased remarkably becoming close to $100 \%$ at 30 days after inoculation. Biochar soil application at 1 and $1.5 \%$, reduced the infection percentages by $33.3 \%$ when the plants were observed 15 days after inoculation with ToMV. Data recorded 30 days post inoculation, showed symptoms development on all plants and protection start to fail.

Disease severity was reduced at all observation dates when tomato plants grown in soil amended with different concentrations of biochar. The highest level of reduction of disease severity was detected at 15 days post inoculation with ToMV, being 50\% with soil biochar amended $1.5 \%$ followed by $37.5 \%$ with $1 \%$ biochar. Applying of biochar $0.5 \%$ reduced the disease index by $25 \%$. After 30 days of inoculation, the effect of biochar was lowered, however, the reduction percentage of disease index was 30,30 and $20 \%$ in plants of biochar amended soil by $1.5,1$ and $0.5 \%$, respectively (Table 1). Hence, reduction of disease severity showed positive relation to biochar concentration increment and negative relation to time of application between 15 and 30 days.

Symptoms of ToMV were observed on leaves of the non-treated infected control (biochar 0\%) (Figure 1E) and on tomato plants grown in $0.5 \%$ biochar amended soil (Figure 1F) as severe mosaic, mottling, blistering, vein clearing, leaf curling companied with leaf malformation whereas, tomato plants grown in $1 \%$ (Figure 1G) and 1.5\% (Figure 1H) biochar amendment rates showed resistance to ToMV symptoms development, as only moderate mosaic symptoms were obtained.

Relative concentrations of ToMV determined by indirect ELISA as absorbance values at $405 \mathrm{~nm}$ presented in Table (2) revealed that virus multiplication was affected by biochar soil treatment. ToMV relative concentration was significantly reduced in tomato plants grown under treatments of biochar 1 and $1.5 \%$.
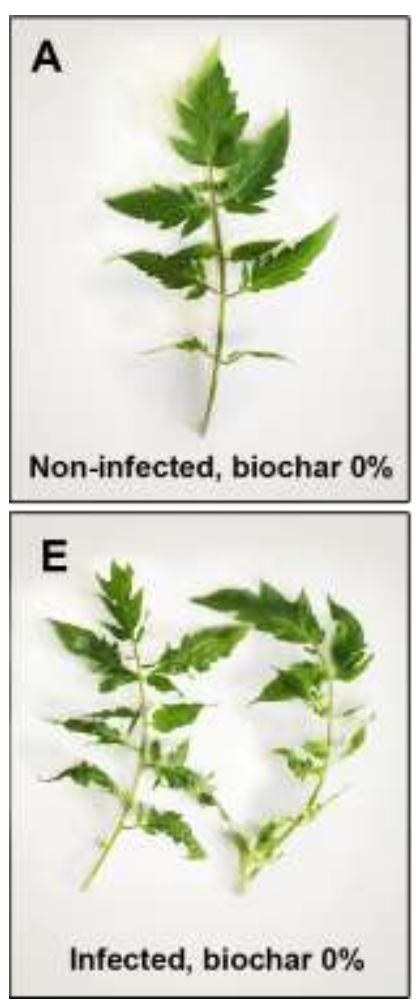
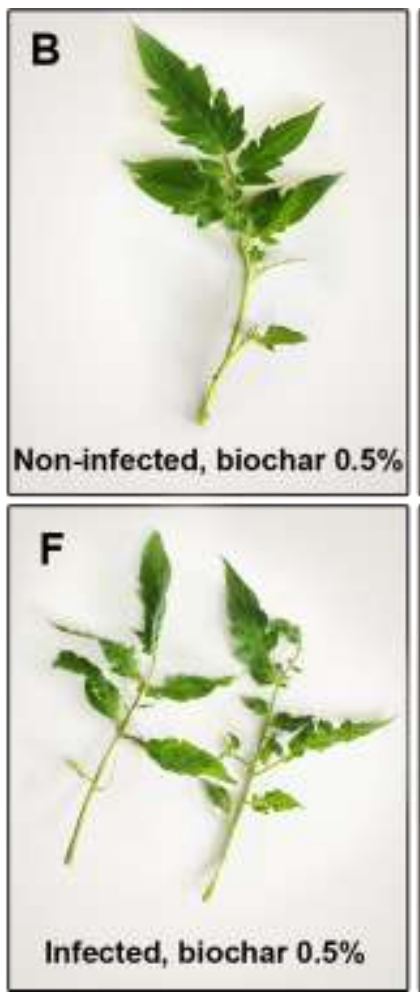
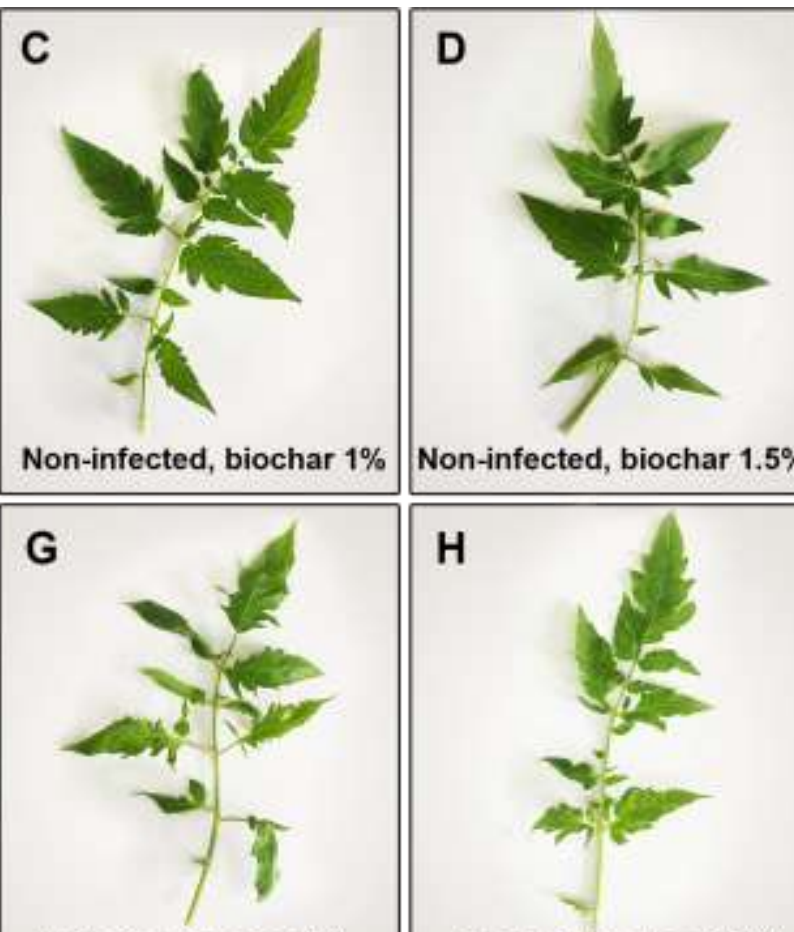

Infected, biochar $1 \%$
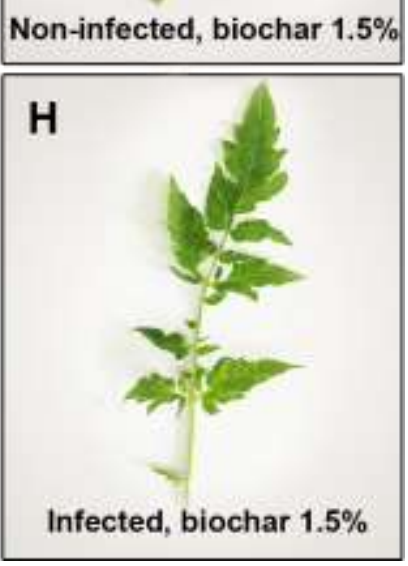

Figure 1. Effect of biochar soil application at different rates on symptoms development of ToMV on tomato plants; ToMV non-infected, grown in (A) biochar 0\%, (B) biochar 0.5\%, (C) biochar 1\%, (D) biochar 1.5\%; ToMV-infected grown in (E) biochar 0\%, (F) biochar 0.5\%, (G) biochar 1\%, (H) biochar 1.5\% 
Table 1. Effect of biochar soil application at different rates on infection percentage (I), disease index (DI) and their reduction \% (R) of ToMV infected plants, 15 and 30 days after inoculation

\begin{tabular}{lcccccccc}
\hline & \multicolumn{8}{c}{ Days after inoculation } \\
\cline { 2 - 10 } Biochar treatment (\%) & \multicolumn{9}{c}{$\mathbf{1 5}$} & \multicolumn{7}{c}{ 30 } \\
\cline { 2 - 10 } & $\mathbf{I}$ & $\boldsymbol{R}$ & DI & $\boldsymbol{R}$ & $\mathbf{I}$ & $\boldsymbol{R}$ & $\mathbf{D I}$ & $\boldsymbol{R}$ \\
\hline $0.0^{*}$ & 100 & 0.0 & 66.7 & 0.0 & 100 & 0.0 & 83.3 & 0.0 \\
0.5 & 100 & 0.0 & 50.0 & 25.0 & 100 & 0.0 & 66.7 & 20.0 \\
1.0 & 66.7 & 33.3 & 41.7 & 37.5 & 100 & 0.0 & 58.3 & 30.0 \\
1.5 & 66.7 & 33.3 & 33.3 & 50.0 & 100 & 0.0 & 58.3 & 30.0 \\
\hline
\end{tabular}

*Plants grown in soil non-treated with biochar and ToMV inoculated.

Table 2. Effect of biochar soil application at different rates on ToMV relative concentration in tomato leaves after 15, 21, 28 and 30 days of inoculation and reduction $\%(\mathbf{R})$

\begin{tabular}{lcccccccc}
\hline \multirow{2}{*}{ Biochar treatment (\%) } & \multicolumn{7}{c}{ Days after inoculation } \\
\cline { 2 - 9 } & $\mathbf{1 5}$ & $\mathbf{R}$ & $\mathbf{2 1}$ & $\mathbf{R}$ & $\mathbf{2 8}$ & $\mathbf{R}$ & $\mathbf{3 5}$ & $\mathbf{R}$ \\
\hline $\mathrm{HC}^{\mathrm{x}}$ & $0.055 \mathrm{~d}$ & - & $0.079 \mathrm{~d}$ & - & $0.081 \mathrm{e}$ & - & $0.082 \mathrm{e}$ & - \\
$0.0^{\mathrm{y}}$ & $0 . n 392 \mathrm{a}$ & - & $0.573 \mathrm{a}$ & - & $0.685 \mathrm{a}$ & - & $0.776 \mathrm{a}$ & - \\
0.5 & $0.367 \mathrm{a}$ & - & $0.541 \mathrm{a}$ & - & $0.636 \mathrm{~b}$ & 7.2 & $0.687 \mathrm{~b}$ & 11.5 \\
1.0 & $0.296 \mathrm{~b}$ & 24.5 & $0.352 \mathrm{~b}$ & 38.6 & $0.515 \mathrm{c}$ & 24.8 & $0.528 \mathrm{c}$ & 31.9 \\
1.5 & $0.234 \mathrm{c}$ & 40.3 & $0.265 \mathrm{c}$ & 53.8 & $0.410 \mathrm{~d}$ & 40.1 & $0.439 \mathrm{~d}$ & 43.4 \\
\hline
\end{tabular}

${ }^{\mathrm{x}} \mathrm{HC}=$ Healthy plants grown in soil non-treated with biochar and ToMV non-inoculated; yPlants grown in soil non-treated with biochar and ToMV inoculated; - data are average of three values (replicates) of ELISA absorbance; The absorbance values of at least double that of the healthy control were considered positive (viral infected); Readings followed by the same letter, within each column, are not significantly different at $p \leq 0.05$.

The highest decrease of ToMV concentration was 53.8 $\%$ and occurred in tomato plants grown in biochar amended soil at $1.5 \%$ when evaluated at 21 days after inoculation. Till 21 days after inoculation, no significant reduction in virus concentration was obtained in tomato plants grown in biochar amended soil with $0.5 \%$ rate. While, after 28 and 35 days of inoculation, minor significant reduction of ToMV relative concentration was obtained being 7.2 and $11.5 \%$, respectively. The impact of the highest rates of biochar 1 and $1.5 \%$ was obvious at 21 days after viral inoculation, then the effect decreased at 28 and 35 days post inoculation. However, the rate $0.5 \%$ needs long time to show the effect. Hence, in line with results of Table (1), reduction of viral concentration showed positive relation to biochar concentration increment and negatively related to time of application after 21 days. Recurrence of other dose of biochar after 21 days may enhance the effect. Delaying symptoms development on tomato plants could be an indicator of tomato resistance to the virus and allow the plant to produce an economic yield, even under viral infection.

It has been reported that biochar application reduced the incidence and severity of several plant viral diseases. Disease severity of Tomato leaf curl virus (TLCV) was significantly reduced in tomato plants treated with different quantities of biochar of maize clipart and was pronounced at the concentration of 3\% (Zeshan et al., 2018). The results of current study are in line with those of Khalifa, (2017) who reported that, soil application with biochar produced from Salix (Salix babylonica) wood chips, suppressed Tobacco mosaic virus (TMV) infection in tomato plants assessed by delaying of symptom appearance, reduction in disease incidence and severity and relative virus concentration. Obvious effects were obtained with the plants treated with 5\% biochar soil application. Also, Bonanomi et al., (2020) found that, tomato plants grown in soil amended with alfalfa straw and biochar showed lower incidence of Tomato spotted wilt virus (TSWV). The effective concentration of biochar differs according to the type of biochar tested and its characteristics.

Biochar can induce systemic plant defenses against wide range of pathogens. It can increase the nutrients availability of plants which improve plant growth and raise the assimilation of inhibitory compounds in the plant tissues (Graber et al., 2014). Moreover, the disease resistance in plants grown in soil supplemented with 
biochar was referred to increase of the total phenolic compounds and peroxidase activity (Khalifa, 2017).

Mainly, the soilborne diseases were investigated in the biochar application studies more than other diseases. The analyses of microbial taxonomy, functional diversity and activity in rhizosphere revealed that the soilborne diseases associated with tomato plants were suppressed due to application of biochar in soil (Jaiswal et al., 2017). Several molecular studies through nextgeneration sequencing analyses demonstrated that usage of biochar alters the microbiome (Jenkins et al., 2017). The induced systemic resistance against Botrytis cinerea in tomato plants grown in biochar amended soil was through the activation of jasmonic acid pathway and early accumulation of hydrogen peroxide (Mehari et al., 2015).

\section{Effect of biochar on the growth of tomato plants}

To determine the effect of soil amendment with different concentrations of studied biochar on the promotion of tomato growth, two growth parameters; fresh weight and dry weight of the shoot were evaluated at the end of the experiment. Data in Table 3 showed that, in case of non-infected tomato, application of biochar caused a significant increase of tomato shoot fresh weight at rate of $1.5 \%$ biochar soil amendment. While, for the ToMV infected tomato, the enhancement of shoot fresh weight appeared at $0.5 \%$ biochar soil amendment. It is noticeable that the beneficial effect depends on the concentration of biochar.

Agronomic advantages and disadvantages of biochar application to agricultural soils in terms of soil geochemistry, soil microflora and fauna, agrochemicals, nutrients and crop yield were reviewed by Kuppusamy et al. (2016). It has been revealed that biochar increased the yield and quality of tomato plants by $20-30 \%$ (Almaroai and Eissa 2020). In another investigation Yilangai et al. (2014) reported that biochar increased the growth of tomato plants. Agbna et al. (2017) indicated that biochar application significantly increased tomato height, leaf number and yield as compared to plants grown in soil without biochar. These results may associate by the improving of soil quality by biochar (Silva et al., 2017) or to be as a result of shifting the microbial population in towards beneficial plant growth promoting rhizobacteria or fungi due to attribution of biochar to soil characteristics (Graber et al., 2010). Several authors reported that, the increase of the growth and productivity of crops growing in soils improved by biochar are due to the enhancement of chemical, physical, and biological properties. Biochar increases nutrient use efficiency and water holding capacity (Hussain et al., 2017). However, several authors put attention to the need of long-term studies on biochar application and sustainable soil health (Lone et al., 2015).

\section{Nutrients uptake of healthy and ToMV-infected} tomato grown in biochar amended soil.

It is well-known that application of organic matters to soil led to increase its fertility (Kulczycki et al., 2020). In order to evaluate the benefit of biochar amendments to uptake of nutrients in tomato plants, the nutritional status of tomato plants grown in soil amended with different rates of biochar was assayed in both healthy and ToMV-infected plants. Nutrients' content of $\mathrm{N}, \mathrm{P}, \mathrm{K}, \mathrm{Ca}, \mathrm{Mg}, \mathrm{S}$ and $\mathrm{Na}$ were determined in the shoot system (Table 4). Non-infected tomato grown in $1.5 \%$ biochar amended soil showed significant increase in $\mathrm{N}$ content. For $\mathrm{K}$ content, the highest significant content was detected at treatment of $1 \%$ biochar amendment for the non-infected tomato and at $1.5 \%$ biochar amendment rate for the ToMV-infected tomato. The biochar addition to soil showed significant diminish in $\mathrm{Na}$ content in case of ToMV-infected tomato at all rates of soil amendments.

Table 3. Effect of biochar soil application on fresh and dry weights of shoot system of tomato plants infected with ToMV

\begin{tabular}{lccc}
\hline Viral infection & $\begin{array}{c}\text { Biochar treatment } \\
(\boldsymbol{\%})\end{array}$ & $\begin{array}{c}\text { Fresh weight } \\
(\mathbf{g})\end{array}$ & $\begin{array}{c}\text { Dry weight } \\
(\mathbf{g})\end{array}$ \\
\hline Non-infected & 0.0 & $28.11 \mathrm{~b}$ & $3.09 \mathrm{ab}$ \\
& 0.5 & $27.69 \mathrm{~b}$ & $3.40 \mathrm{a}$ \\
& 1.0 & $26.56 \mathrm{~b}$ & $2.71 \mathrm{abc}$ \\
Infected & 1.5 & $35.31 \mathrm{a}$ & $2.69 \mathrm{abc}$ \\
& 0.0 & $14.85 \mathrm{~d}$ & $1.65 \mathrm{~d}$ \\
& 0.5 & $19.56 \mathrm{c}$ & $2.30 \mathrm{bcd}$ \\
& 1.0 & $15.54 \mathrm{~d}$ & $1.69 \mathrm{~d}$ \\
& 1.5 & $12.94 \mathrm{~d}$ & $1.91 \mathrm{dc}$ \\
\hline
\end{tabular}

- Means followed by the same letter(s), within each column, are not significantly different at $p \leq 0.05$. 
Table 4. Macronutrients and Na content in shoots of ToMV infected tomato plants grown in biochar amended soil

\begin{tabular}{lcccccccc}
\hline \multirow{2}{*}{$\begin{array}{l}\text { Viral } \\
\text { infection }\end{array}$} & $\begin{array}{c}\text { Biochar } \\
\text { treatment }(\%)\end{array}$ & $\mathbf{N}$ & $\mathbf{P}$ & $\mathbf{K}$ & $\mathbf{C a}$ & $\mathbf{M g}$ & $\mathbf{N a}$ & $\begin{array}{c}\text { S } \\
(\mathbf{m g} / \mathbf{k g})\end{array}$ \\
\cline { 3 - 7 } & 0.0 & $2.00 \mathrm{ab}$ & $0.64 \mathrm{a}$ & $21.12 \mathrm{~h}$ & $0.119 \mathrm{a}$ & $1.226 \mathrm{a}$ & $11.39 \mathrm{c}$ & $2.14 \mathrm{a}$ \\
Non- & 0.5 & $2.14 \mathrm{a}$ & $0.53 \mathrm{a}$ & $24.55 \mathrm{f}$ & $0.116 \mathrm{a}$ & $1.359 \mathrm{a}$ & $12.55 \mathrm{~b}$ & $2.00 \mathrm{a}$ \\
infected & 1.0 & $2.11 \mathrm{ab}$ & $0.55 \mathrm{a}$ & $41.82 \mathrm{a}$ & $0.127 \mathrm{a}$ & $1.299 \mathrm{a}$ & $14.69 \mathrm{a}$ & $2.14 \mathrm{a}$ \\
& 1.5 & $2.10 \mathrm{ab}$ & $0.48 \mathrm{a}$ & $26.64 \mathrm{e}$ & $0.118 \mathrm{a}$ & $1.250 \mathrm{a}$ & $12.52 \mathrm{~b}$ & $2.46 \mathrm{a}$ \\
& 0.0 & $1.89 \mathrm{~b}$ & $0.60 \mathrm{a}$ & $31.78 \mathrm{c}$ & $0.112 \mathrm{a}$ & $1.145 \mathrm{a}$ & $11.13 \mathrm{~d}$ & $2.35 \mathrm{a}$ \\
Infected & 0.5 & $1.88 \mathrm{bc}$ & $0.50 \mathrm{a}$ & $30.03 \mathrm{~d}$ & $0.081 \mathrm{a}$ & $1.209 \mathrm{a}$ & $9.15 \mathrm{f}$ & $2.10 \mathrm{a}$ \\
& 1.0 & $1.88 \mathrm{bc}$ & $0.53 \mathrm{a}$ & $22.53 \mathrm{~g}$ & $0.098 \mathrm{a}$ & $1.239 \mathrm{a}$ & $9.02 \mathrm{f}$ & $2.08 \mathrm{a}$ \\
& 1.5 & $1.90 \mathrm{ab}$ & $0.56 \mathrm{a}$ & $34.07 \mathrm{~b}$ & $0.097 \mathrm{a}$ & $1.203 \mathrm{a}$ & $9.91 \mathrm{e}$ & $2.17 \mathrm{a}$ \\
\hline
\end{tabular}

- Means followed by the same letter(s), within each column, are not significantly different at $p \leq 0.05$.

Biochar amendment has proven to modify soil nutrients availability which may explain the enhancement of plant biomass. Biochar increased the potential difference between rhizosphere and root membrane which lowered the free energy required for nutrient uptake by root and ultimately increase plant biomass (Chew et al., 2020). Potassium played an important role in enzyme functions and regulations of metabolism ways and metabolite levels, which may lead to increase of the synthesis of high molecular weight compounds like proteins, starch and cellulose and reduce the concentration of low molecular weight compounds as soluble sugars, organic acids and amino acids in plant tissues. The low molecular weight compounds are vital for infection developments (Marschner, 2012; Wang et al., 2013). Potassium fertilization decreased the incidence of disease in many host plants, but sometimes had no effect or even a contradictory effect (Perrenoud, 1990; Wang et al., 2013). The variable effect of potassium on disease incidence may differed according to the amount and source of potassium, plant, pathogen and experiment conditions (Wang et al., 2013). Symptoms and disease percentage of Potato virus $X$ (PVX), Potato virus $Y$ (PVY) and Potato leaf roll virus (PLRV) was reduced in potato plants treated with potassium citrate and folic acid (Ibrahim et al., 2015). The mechanisms of potassium effect on plant resistance against several disease was summarized as; high concentration of potassium decreased the internal competition of pathogens for nutrient resources. Therefore, the cell wall became stronger which help to prevent the pathogen infection (Mengel and Kirkby, 2001). Singh and Mall (1974) indicated that, different levels of potassium up to $250 \mathrm{ppm}$ gradually increased the vegetative, root growth and PVX concentration in tomato plants. Treatment with high doses of potassium in the form of KCL of rice plants variety Bouake 189 infected with Rice yellow mottle virus (RYMV) decreased the effect of viral infection on grain production (Soko et al., 2017). Adequate potassium increases phenol concentrations which have a critical role in plant resistance which led to decrease in disease severity (Prasad et al., 2010).

It has been revealed that biochar amendments to soil increases $\mathrm{K}$ uptake. The symptoms of $\mathrm{K}$ deficiency did not observe in cucurbita seedling grown in biochar amended soil and the plants were healthy and greener (Islam et al., 2019). The dynamics of soil potassium was enhanced through biochar amendments which facilitate $\mathrm{K}$ uptake by plants (Wang et al., 2018). In another study, it was suggested that application of biochar at low doses with the synthetic fertilizers can improve plant yield and soil fertility (Kulczycki et al., 2020). Application of biochar may reduce Na uptake by plants which allow for survival and growth under salinity conditions (Farhangi-Abriz and Torabian, 2018). Tomato plants grown in soil amended with biochar and irrigated with saline water showed tolerance to salinity depending on salt concentration and biochar application rate (Agbna et al., 2017 and She et al., 2018). Biochar application could be an environmental solution for carbon sequestration, improving agricultural soil characteristics and enhancing plant yield in terms of quantity and quality.

\section{CONCLUSIONS}

Biochar amendment to agricultural soil was used as a method to recycle the plant organic residuals for tomato plant fertilization and suppressor for controlling ToMV. The growth and nutrient uptake in tomato plants were assessed as well. Three amendment rates of biochar were used $0.5,1.0$, and $1.5 \%$. The effect was obvious for plant amended with $1 \%$ and $1.5 \%$ as evidenced by delaying of symptoms development, decrease in disease severity and decline of relative virus 
content. The shoot fresh weight was significantly increased at biochar amendments rates of $1.5 \%$ and $0.5 \%$ in non-infected and ToMV infected tomato, respectively. Potassium content in shoot of non-infected and ToMV-infected tomato grown in biochar treatment of $1.0 \%$ and $1.5 \%$ was significantly increased. The content of $\mathrm{N}, \mathrm{P}, \mathrm{Ca}, \mathrm{Mg}$, and $\mathrm{S}$ did not affect.

Generally, biochar application to agricultural soil could be a safe and promising solution for carbon sequestration, enhance plant disease resistance and increase yield and quality of agricultural crops. However, further studies are needed to investigate the effect of recurrence of biochar supplement to activate its antiviral effect, as well as to determine the mechanisms responsible for biochar induced systemic resistance against ToMV and other plant viruses affecting tomato plants.

\section{ACKNOWLEDGMENTS}

The authors would like to express appreciation for prof. Mohamed Anwar El-Saedy, Professor of Plant Pathology, Alexandria University, Egypt for helping in statistical analysis.

Conflicts of Interests: The authors declare no conflict of interest.

\section{REFERENCES}

Agbna, G. H. D., A. A. S. Ali, M. M. A. Elbashier, M. Bakir, A. Osman and A. E. A. Elshaikh. 2017. Effect of biochar on some soil properties and tomato growth under saline water conditions. I.J.S.E.R., 8(4):24- 28

Agrios, G. N. 2005. Plant pathology. $5^{\text {th }}$ ed. Elsevier Academic Press., pp 922.

Almaroai, Y. A. and M. A. Eissa. 2020. Effect of biochar on yield and quality of tomato grown on a metalcontaminated soil. Sci. Hortic., 265:109210

A.O.A.C. 1992. Official Methods of Analysis. $12^{\text {th }}$ Ed. Association of Official Analytical Chemists. Washington, D.C., U.S.A. 1959p.

Bonanomi, G., D. Alioto, M. Minutolo, R. Marra, G. Cesarano and F. Vinale. 2020. Organic amendments modulate soil microbiota and reduce virus disease incidence in the TSWV-tomato pathosystem. Pathogens, 9:379.

Brown, J.D. and O. Lilliland. 1946. Rapid determination of potassium and sodium in plant material and soil extracts by flame photometry. Proc. Amer. Soc. Hort. Sci., 48:341346.

Brunt, A. A., K. Crabtree, M. J. Dallwitz, A. J. Gibbs and L. Watson. 1996. Viruses of plants: Descriptions and Lists from the VIDE Database. CAB International, 1484p.

Butters, B. and E. M. Chenery. 1959. A rapid method for the determination of total sulphur in soils and plants. Analyst, 84:239-245.
Chapman, H. D. and P. F. Pratt. 1961. Methods of analysis for soils, plants and waters. University of California, Citrus Experiment Station, Riverside.

Cheng, K. L. and R. H. Bray. 1951. Determination of Ca and $\mathrm{Mg}$ in soil and plant material. Soil Science, 72:449-458.

Chew, J., L. Zhu, S. Nielsen, E. Graber, D. R. G. Mitchell, J. Horvat, M. Mohammed, M. Liu, L. van Zwieten, S. Donne, P. Munroe, S. Taherymoosavi, B. Pace, A. Rawal, J. Hook, C. Marjo, D. S. Thomas, G. Pan, L. Li, R. Bian, A. McBeath, M. Bird, T. Rhomas, O. Husson, Z. Soliman, S. Joseph and X. Fan. 2020. Biochar-based fertilizer: Supercharging root membrane potential and biomass yield of rice. Sci. Total Environ., 713:136431.

Elad, Y., E. Cytryn, Y. Meller Harel, B. Lew and E. R. Graber. 2011. The Biochar effect: plant resistance to biotic stresses. Phytopathol. Mediterr., 50:335-349.

FAO. 2018. FAOSTAT. In: Crops, Rome. http://www.fao.org/faostat/en/\#data/QC

Farhangi-Abriz, S. and S. Torabian. 2018. Effect of biochar on growth and ion contents of bean plant under saline condition. Environ. Sci. Pollut. R., 25: 11556-11564.

Fegla, G. I., I. A. El-Samra, K. A. Nouman and H. A. Younes. 1997. Host range, transmission and serology of an isolate of Tomato yellow leaf curl virus from tomato of plastic houses in northern Egypt. Proc. $1^{\text {st }}$ Sci. Conf. Agric. Sci. Assiut University, Assiut, Egypt, 549-568.

Graber, E. R., Y. M. Harel, M. Kolton, E. Cytryn, A. Silber, D. R. David, L. Tsechansky, M. Borenshtein and Y. Elad. 2010. Biochar impact on development and productivity of pepper and tomato grown in fertigated soilless media. Plant Soil, 337:481-496.

Graber, E. R., O. Frenkel, A. K. Jaiswal and Y. Elad. 2014. How may biochar influence severity of diseases caused by soilborne pathogens? Carbon Manag., 5(2):169-183.

Hančević, K., S. Černi, T. Radić and D. Škorić. 2012. Comparison of different methods for Citrus tristeza virus detection in Satsuma mandarins. J. Plant Dis. Protect., 119(1):2-7.

Hussain, M., M. Farooq, A. Nawaz, A. M. Al-Sadi, Z. M. Solaiman, S. S. Alghamdi, U. Ammara, Y. S. Ok and K. H. M. Siddique. 2017. Biochar for crop production: potential benefits and risks. J. Soils Sediments., 17:685716.

Ibrahim, M. F. M., H. G. Abd El-Gawad and A. M. Bondok. 2015. Physiological impacts of potassium citrate and folic acid on growth, yield and some viral diseases of potato plants. Middle East J. Agric. Res., 4(3): 577-589.

ICTV. 2014. International Committee on Taxonomy of viruses. Www.ictvonline.org.

Islam, M., M. Halder, Md. A. B. Siddique, S. A. A. Razir, S. Sikder and J. C. Joardar. 2019. Banana peel biochar as alternative source of potassium for plant productivity and sustainable agriculture. I.J. R.O.W.A., 8 (Suppl 1):54075413.

Jaiswal, A. K., Y. Elad, I. Paudel, E. R. Graber, E. Cytryn and O. Frenkel. 2017. Linking the belowground microbial composition, diversity and activity to soilborne disease suppression and growth promotion of tomato amended with biochar. Sci. Rep., 7:44382 
Jenkins, J. R., M. Viger, E. C. Arnold, Z. M. Harris, M. Ventura, F. Miglietta, C. Girardin, R. J. Edwards, C. Rumpel, F. Fornasier, C. Zavalloni, G. Tonon, G. Alberti and G. Taylor. 2017. Biochar alters the soil microbiome and soil function: results of next-generation amplicon sequencing across Europe. G.C.B. Bioenergy, 9(3):591612.

Johnson, C. M. and A. Ulrich. 1959. Analytical methods for use in plant analysis. Bull. Calif. Agric. Exp. Sta., 78pp.

Kawanna, M. A. and G. I. Fegla. 2015. Comparison between indirect ELISA and TBIA for detection of some viruses in naturally infected faba bean plants. A.R.R.B., 7(4):275282.

Khalifa, W. 2017. Biochar soil amendment induced resistance in tomato against Tobacco mosaic virus. Middle East J. Agric. Res., 6(4):1478-1489.

Koenig, R. 1981. Indirect ELISA methods for the broad specificity detection of plant viruses. J. Gen. Virol., 55:5362.

Kulczycki, G., E. G. Magnucka, M. P. Oksińska, J. Kucińska, R. Kobylecki, K. Pawęska, R. Zarzycki, A. Kacprzak and S. J. Pietr. 2020. The effect of various types of biochar mixed with mineral fertilization on the development and lonome of winter wheat (Triticum aestivum L.) seedlings and soil properties in a pot experiment. Agronomy, 10,1903 .

Kuppusamy, S., P. Thavamani, M. Megharaj, K. Venkateswarlu and R. Naidu. 2016. Agronomic and remedial benefits and risks of applying biochar to soil: Current knowledge and future research directions. Environ. Int., 87:1-12.

Lehmann, J., J. Gaunt and M. Rondon. 2006. Bio-char sequestration in terrestrial ecosystems - A review. Mitig. Adapt. Strat. Gl., 11:403-427.

Lone, A. H., G. R. Najar, M. A. Ganie, J. A. Sofi and T. Ali. 2015. Biochar for sustainable soil health: A review of prospects and concerns. Pedosphere, 25(5):639-653.

Mahmoud, A. H., M. E. Saleh and A. A. Abdel-Salam. 2011. Effect of rice husk biochar on cadmium immobilization in soil and uptake by wheat plant grown on lacustrine soil. Alex. J. Agric. Res., 56(2):117-125.

Marschner, P. 2012. Marschner' Mineral Nutrition of Higher Plants. $3^{\text {rd }}$ ed., Academic Press, London, UK, 178-189.

Mehari, Z. H., Y. Elad, D. Rav-David, E. R. Graber and Y. M. Harel. 2015. Induced systemic resistance in tomato (Solanum lycopersicum) against Botrytis cinerea by biochar amendment involves jasmonic acid signaling. Plant Soil, 395:31-44.

Mengel, K. and E. A. Kirkby. 2001. Principles of plant nutrition. Kluwer Academic Publishers, Dordrecht, the Netherlands. 849 pp.

Mostafa, F. A. and Kh. A. H. Shaban. 2019. Effect of different types of biochar on chemical properties, microbial community, pathogenic fungi and faba bean productivity. S. J. A. S., 1(2):72-87.
Ong, S. N., S. Taheri, R. Y. Othman and C. H. Teo. 2020. Viral diseases of tomato crops (Solanum lycopersicum L.): an overview. J. Plant Dis. Protect., 127:725-739.

Perrenoud, S. 1990. Potassium and plant health, $2^{\text {nd }}$ ed. IPI Research Topics No.3, International Potash Institute, Bern, Switzerland, 365pp.

Prasad, D., R. Singh, and A. Singh. 2010. Management of sheath blight of rice with integrated nutrients. Indian Phytopath., 63(1):11-15.

Raupach, G. S., L. J. Liu, F. Murphy, S. Tuzun and J. W. Kloepper. 1996. Induced systemic resistance in cucumber and tomato against cucumber mosaic cucumovirus using plant growth- promoting rhizobacteria (PGPR). Plant Dis., 80: 891-894.

SAS Institute. 1997. SAS/STAT User's Guide. Release 6.03 Edition. SAS Institute Inc., North Carolina, Cury. Inc. 1028pp.

Sastry, K.S., B. Mandal, J. Hammond, S. W. Scott and R. W. Briddon. 2019. Encyclopedia of plant viruses and viroids. $1^{\text {st }}$ ed. Springer India, 2936.

She, D., X. Sun, A. H. D. Gamareldawla, E. A. Nazar, W. Hu, K. Edith and S. Yu. 2018. Benefits of soil biochar amendments to tomato growth under saline water irrigation. Sci. Rep., 8, 14743.

Silva, I. C. B., L. A. Fernandes, F. Colen and R. A. Sampaio. 2017. Growth and production of common bean fertilized with biochar. Ciênc. Rural, 47(11):1-8.

Singh, R. and T. P. Mall. 1974. Effect of potassium nutrition on plant growth and multiplication of Potato virus $X$ in tomato. Chemical Era. X.11:47-49.

Soko, D. F., M. A. D. Boye, L. A. C. Siene and S. Ake. 2017. Effect of nitrogen and potassium on the expression of sensitivity and variety resistance to Rice yellow mottle virus. I. J. I. S. E. T., 4(11): 224-232.

Wang, M., Q. Zheng, Q. Shen and S. Guo. 2013. The critical role of potassium in plant stress response. Int. J. Mol. Sci., 14(4):7370-7390.

Wang, L., C. Xue, X. Nie, Y. Liu and F. Chen. 2018. Effect of biochar application on soil potassium dynamics and crop uptake. J. Plant Nutr. Soil Sci., 181(5):635-643.

Yilangai, R. M., S. A. Manu, W. Pineau, S. S. Mailumo and K. I. Okeke-Agulu. 2014. The effect of biochar and crop veil on growth and yield of tomato (Lycopersicum esculentus Mill) in Jos, North central Nigeria. Curr. Agri. Res. Jour., 2(1):37-42

Zeshan, M. A., Y. Iftikhar, S. Ali, N. Ahmed, M. Ghani, M. Kamran and Q. N. Khan. 2018. Induction of resistance in tomato plants against Tomato leaf curl virus by using biochar and seed priming. Pak. J. Phytopathol., 30(1):1925 . 
الملخص العربي

تأثير تحسين التربة بالفحم الحيوى (Biochar) على الاصابة بفيروس موزايك الطماطر ونمو وامتصاص العناصر المغذية فى نباتات الطماطم

$$
\text { مها عادل كونه، أحمد فرج البيبانى، أيمن بسيونى عبده بسيونى }
$$

الرطب للمجموع الخضرى فى حالة استخدام الفحم الحيوى بتركيزات 1 , و 0, • \% فى النباتات الغير مصابة والنباتات المصابة، على الترتيب. وظهرت زيادة معنوية فى محتوى

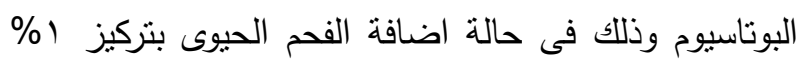
للنباتات السليمة وتركيز 0, 1\% للنباتات المصابة بالفيروس. بينما انخفض نركيز الصوديوم فى المجموع الخضرى للنباتات

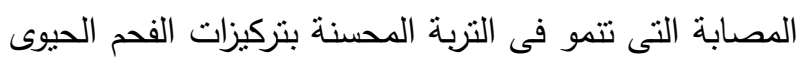

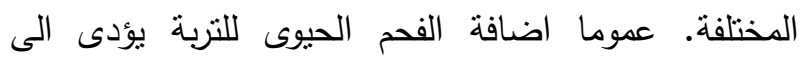
تحسين المقاومة للاصابة بفيروس موزايك الطماطم وتحفيز النمو وزيادة البوتاسيوم ونقص الصوديوم بنباتات الطماطم. يعتبر تطبيق اضافة الفحم الحيوى للتربة الزراعية طريقة عملية لتقليل نأثنر التغيرات المناخية من خلال احتباس الكربون وتحسين انتاجية النبات وزيادة تحمله للأمراض من من

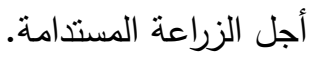

الكلمات المفتاحية: الطماطم، الفحم الحيوى، فيروس موزايك الطماطم، المقاومة، البوتاسيوم، الصوديوم.
يعتبر تحسين التربة باستخدام الفحم الحيوى من الطرق

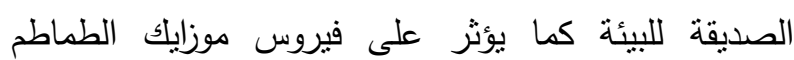
Tomato mosaic virus (ToMV) لنباتات الطماطم. تم استخدام ثثلثة تركيزات من الفحم الحيوى 0, •، 1، 0, 1\%. فاضافة الفحم الحيوى للتربة بتركيز 1، 1,0 أدى الى تقليل حدوث الاصنابة بالفيروس

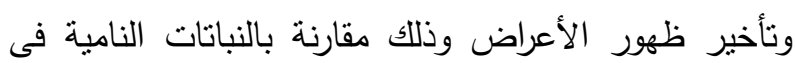
تربة خالية من الفحم الحيوى. وانخفضت نسبة الاصابة وشدة المرض بالفيروس بنسبة r,rس و •0\% على الترتيب وذلك بعد 10 يوم من العدوى فى النباتات النامية فى تربة معاملة

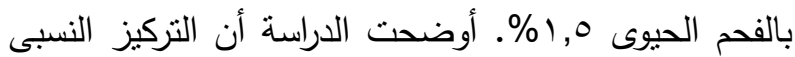
للفيروس باستخدام اختبار الاليزا غبر المباشرة Indirect) ELISA) بالفحم الحيوى بتركيز ا و 0,1\%. وقد تحقق أقل تركيز للفيرس فى النباتات التى تتمو فى تربة محسنة باضافة الفحم

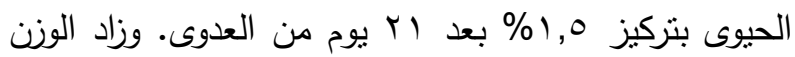

